\section{Peranan Customer Servis \\ Dalam Meningkatkan Mutu Pelayanan \\ Pada Sekolah Islam Ibnu Hajar}

\author{
Fini Rizkita Purnama Ayudan Wimpi Srihandoko \\ Program Studi Perbankan dan Keuangan, Institut Bisnis dan Infromatika Kesatuan \\ E - Mail : fini.rizkita@ibik.ac.id
}

Implementation of

Service Quality in

Education Sector

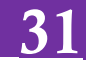

Submitted

JANUARI 2021

Accepted

JULI 2021

\begin{abstract}
Customer Service is an activity aimed at providing satisfaction through the Services provided by someone to their clients in solving problems and satisfying. Customer Service is one of the facilities provided by the school to serve student and parents, so that parents feel well facilitated by the school. The purpose of making this thesis, to find out how the role of Customer Service in improving the quality of Service at Ibnu Hajar Islamic School. And find out the Customer Service, Service strategy in improving the quality of Service at Ibnu Hajar Islamic School. The results of the discussion showed that, the way to improve the quality of Service is to listen patiently to all complaints and questions from student guardians. And can control emotions if you have previously served the complaining, then came the others.still smiling does not vend to others and applies several ways, namely by being friendly and communicative and serving wholeheartedly, so that parents feel statisfied with the Services provided. While the constraints faced by Customer Service are, overflowing complaints that are excessive, the lack of respect for Customer Service and impatience when waiting to be served.
\end{abstract}

Keyword : Customer Service, school, application

\begin{abstract}
ABSTRAK
Customer Service merupakan kegiatan yang ditujukan untuk memberikan kepuasaan melalui pelayanan yang diberikan oleh seseorang kepada kliennya dalam menyelesaikan masalah dan memuaskan. Customer Service merupakan salah satu fasilitas yang di berikan pihak sekolah untuk melayani murid dan wali murid, agar para orang tua merasa terfasilitasi dengan baik oleh pihak sekolah. Tujuan dari pembuatan tugas akhir ini, untuk mengetahui bagaimana peran Customer Service dalam meningkatkan mutu pelayanan pada Sekolah Islam Ibnu Hajar. dan mengetahui kendala Customer Service dalam meningkatkan mutu pelayanan pada Sekolah Islam Ibnu Hajar. Serta mengetahui strategi pelayanan Customer Service dalam meningkatkan mutu pelayanan pada Sekolah Islam Ibnu Hajar. Hasil pembahasan menunjukan bahwa, cara meningkatkan mutu pelayanan adalah dengan mendengarkan dengan sabar semua keluhan dan pertanyaan dari wali murid. Serta bisa mengendalikan emosi jika sebelumnya sudah melayani yang mengeluh, lalu datang yang lain. Tetap tersenyum tidak melampiaskan kepada yang lain dan menerapkan beberapa cara yaitu, dengan bersikap ramah dan komunikatif melayani dengan sepenuh hati, sehingga wali murid merasa puas dengan pelayanan yang di berikan. Sedangkan kendala-kendala yang di hadapi oleh Customer Service yaitu, Melupakan keluhan yang berlebuhan, minimnya menghargai Customer Service dan tidak sabar ketika menunggu untuk di layani.
\end{abstract}

JABKES

Kata Kunci : Customer Service.

\title{
PENDAHULUAN
}

Setiap instansi atau lembaga selalu mengalami persaingan yang semakin ketat mengikuti perkembangan zaman. Di era globalisasi saat ini, suatu lembaga atau instansi 
Implementation of Service Quality in Education Sector

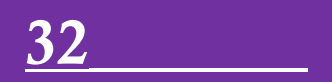

untuk bisa mencapai keberhasilan visi dan misi perlu adanya inovasi agar menjadi lembaga yang unggul dari para pesaingnya.

Besarnya modal yang dimiliki serta penggunaan teknologi maupun sarana tidak bisa menjadi tolak ukur keberhasilan suatu lembaga dalam mencapai tujuan sesuai dengan visi dan misi. Agar suatu instansi atau lembaga mempunyai citra yang baik dimata konsumen dan masyarakat salah satunya ada faktor pelayanan dengan cara memiliki fasilitas pelayanan yang baik.

Untuk menjaga dan meningkatkan kepercayaan konsumen, lembaga harus menjaga citranya ini dapat terjaga salah satunya melalui kualitas pelayanan yang diberikan oleh lembaga tersebut. Untuk meningkatkan citranya, lembaga memerlukan karyawan yang di harapkan dapat melayani kebutuhan konsumen. Inilah yang di sebut Customer Service atau ada juga yang menyebutnya Service assitance.

Menurut (Kasmir, 2005), pengertian Customer Service secara umum adalah :

Kegiatan yang diperuntukkan atau ditujukan untuk memberikan kepuasan kepada konsumen, melalui pelayanan yang dapat memenuhi kegiatan dan kebutuhan nasabah. Customer Service mempunyai peranan yang sangat penting selain melayani kebutuhan konsumen, Customer Service juga harus bisa memberikan solusi terhadap keluhan yang di Alami konsumen.

Pelayanan merupakan tindakan yang di lakukan untuk memberikan kepuasaan kepada konsumen pelayanan dapat di lakukan secara langsung, artinya karyawan langsung berhadapan dengan konsumen. Adapun pelayanan tidak langsung pelayanan yang dilakukan melalui sosial media. Dalam melayani nasabah hal-hal yang perlu diperhatikan adalah kepuasaan konsumen terhadap pelayanan yang diberikan. Dalam praktiknya, pelayanan yang baik memiliki ciri tersendiri. Yang mempengaruhi pelayanan yang baik adalah karyawan, dimana dalam melayani konsumen harus memiliki kemampuan komunikasi yang baik, sopan santun dan bertanggung jawab penuh serta mampu melayani dengan cepat dan tepat.

Konsumen merupakan asset yang sangat penting didalam dunia pendidikan karena itu wajib hukumnya bagi karyawan untuk memberikan pelayanan yang baik kepada konsumen, untuk memberikan pelayanan yang terbaik terlebih dahulu kita harus dapat mengetahui karakteristik setiap konsumen.

Sebelum memahami dan menjalankan tugasnya, seorang Customer Service perlu memahami konsep dari pelayanan yang menjadi inti tugasnya sehari-hari. Pemahaman atas konsep pelayanan akan menjadi modal dasar bagi Seorang Customer Service untuk bisa melayani nasabah dengan sempurna. Kata pelayanan, secara etimologis dalam Kamus Besar Bahasa Indonesia mengandung arti "usaha memenuhi kebutuhan orang lain, pelayanan pada dasarnya kegiatan yang di tawarkan kepada konsumen yang dilayani, yang bersifat tidak berwujud dan tidak dapat di miliki".

Menurut Kamus Besar Bahasa Indonesia, Pelayanan kemudahan yang diberikan sehubungan dengan proses jual beli barang atau jasa. Pelayanan merupakan setiap tindakan atau kegiatan yang dapat ditawarkan oleh satu pihak kepada pihak lain yang pada dasarnya tidak berwujud dan tidak mengakibatkan kepemilikan apapun.

Menurut Kotler, Pelayanan (Service) adalah setiap tindakan atau perbuatan yang dapat ditawarkan oleh suatu pihak lain yang pada dasarnya bersifat intangible ( tidak berwujud fisik ) dan tidak menghasilkan sesuatu.

Menurut ( Moenir, 2008 ) pengertian Customer Service adalah :

Kegiatan yang dilakukan oleh seseorang atau sekelompok orang yang berdasarkan faktor materialnya melalui sistem, prosedur, dan metode tertentu dalam rangka usaha memenuhi kegiatan dan kebutuhan konsumen.

Customer Service adalah upaya memberikan layanan (Service) kepada pelanggan (customer) sesuai kontrak yang telah disepakati. Menurut Suharto Abdul Majid dalam bukunya yang berjudul Customer Service dalam Bisnis Jasa Transportasi (2009) menjelaskan tentang Customer Service adalah sebagai ilmu dan seni dalam pemasaran (marketing) dan penjualan (sales). Artinya, bahwa Customer Service sangat membutuhkan 
unsur kreativitas, inisiatif atau kepandaian dan keterampilan dalam berhubungan dengan orang lain. Jadi, Customer Service merupakan ilmu sekaligus seni dalam melayani orang lain/pelanggan.

Customer Service merupakan suatu bagian dari unit organisasi yang berfungsi sebagai informasi dan perantara bagi konsumen yang ingin mendapatkan jasa-jasa pelayanan. Pelayanan yang diberikan adalah pelayanan yang berdasarkan informasi dan pelayanan jasa yang tujuannya untuk memberikan kepuasan kepada konsumen dan dapat memenuhi keinginan dan kebutuhan konsumen. Pelayanan yang diberikan oleh seorang petugas Customer Service haruslah mencerminkan pendekatan seutuhnya dari seorang karyawan kepada konsumen. Hal ini dilakukan dengan sikap saling membantu, bersahabat dan bersikap profesional.

Kunci utama dalam meningkatkan mutu pelayanan yaitu dengan mengoptimalisasi sumber daya manusia khususnya Customer Service. Customer Service merupakan faktor yang paling utama dalam menentukan suatu keberhasilan suatu organisasi dalam bidang pelayanan. Di perlukan Customer Service yang memiliki keahlian yang baik untuk melayani konsumen.

Sekolah Islam Ibnu Hajar merupakan sebuah instansi yang bergerak di dunia pendidikan khususnya tingkat Sekolah Dasar (SD), Sekolah Menengah Pertama (SMP) dan Sekolah Menengah Atas (SMA). Dari tahun ke tahun, jumlah siswa di Sekolah Islam Ibnu Hajar selalu mengalami peningkatan. Hal ini menunjukan bahwa Sekolah Islam Ibnu Hajar semakin diminati di kalangan masyarakat. Maka dari itu Sekolah Islam Ibnu Hajar harus tetap mempertahankan eksistensinya agar dapat unggul diantara sekolah lain yang menjadi pesaingnya.

Pelayanan yang baik menjadi faktor yang penting bagi Sekolah Islam Ibnu Hajar dalam mempertahankan eksistensinya karena dengan pelayanan yang baik, orang tua dan siswa terfasilitasi dengan baik. Sekolah Islam Ibnu Hajar berupaya melakukan pelayanan yang terbaik untuk orang tua dan siswa. Dengan diadakannya Customer Service ini, di harapkan dapat melayani kebutuhan orang tua dan siswa dengan cepat dan tanggap.

Selain itu, orang tua juga bisa dengan mudah memperoleh informasi mengenai sekolah.

Dengan adanya Customer Service ini para orang tua juga merasa aman karena siswa tidak boleh dijemput jika penjemput tidak membawa identitas penjemputan yang diberikan oleh pihak sekolah sebelumnya. Hal ini diterapkan agar tidak terjadi hal-hal yang tidak diinginkan. Sehingga para orang tua tidak merasa khawatir atas keselamatan anak-anak mereka, dan jika orang tua tidak sempat menjemput langsung dan menggunakan transportasi online maka data penjemput akan di verifikasi terlebih dahulu oleh Customer Service.

Selain itu, jika ada calon orang orang tua siswa yang datang akan mendaftarkan anaknya untuk bersekolah di Sekolah Islam Ibnu Hajar dan ingin mengetahui lebih dalam tentang lingkungan Sekolah Islam Ibnu Hajar, maka Customer Service juga akan mengajak calon orang tua siswa berkelililing melihat lingkungan sekolah secara langsung sambil memberikan penjelasan kepada calon orang tua siswa sehingga calon orang tua siswa betul-betul memahami lingkungan sekolah sehingga calon orang tua siswa merasa yakin untuk menyekolahkan anaknya ke Sekolah Islam Ibnu Hajar.

Selain secara offline, Customer Service juga memberi pelayanan melalui online seperti telephone, email, faks dan whatsapp. Selain mampu berkomunikasi dengan baik, Customer Service juga di tuntut untuk menyimpan semua catatan interaksi konsumen untuk memperbaiki kualitas pelayanan agar lebih baik.

Dengan adanya Customer Service ini, pihak sekolah berharap mampu menjadi wadah bagi para orang tua untuk mendapatkan informasi secara akurat mengenai sekolah. Selain itu menjadi tempat untuk menyampaikan keluhan serta mampu memberikan solusi yang tepat terhadap keluhan yang disampaikan. Selain itu, dengan adanya Customer Service ini mampu memberikan citra yang baik untuk sekolah dimata orang tua dan masyarakat. Jika sekolah sudah mempunyai citra positif dimata orang tua dan masyarakat, maka akan memberikan dampak yang baik salah satunya sekolah akan semakin terkenal melalui 
informasi dari satu orang kepada orang lain, dan para orang tua tidak ragu untuk menyekolahkan anaknya di Sekolah Islam Ibnu Hajar.

\section{Identifikasi Masalah}

Kendala Customer Service dalam meningkatkan mutu pelayanan pada Sekolah Islam Ibnu Hajar

\section{Maksud dan Tujuan Penelitian}

a. Mengetahui kendala Customer Service dalam meningkatkan mutu pelayanan pada Sekolah Islam Ibnu Hajar.

b. Mengetahui Strategi pelayanan Customer Service dalam meningkatkan mutu pelayanan di Sekolah Islam ibnu Hajar.

\section{HASIL DAN PEMBAHASAN}

\section{Sejarah Sekolah Islam Ibnu Hajar}

Sekolah Islam Ibnu Hajar adalah sekolah bernuansakan islam dengan konsep alam. Sekolah ini menawarkan suasana sekolah yang asri, dengan pemandangan yang indah serta arena bermain yang luas, sehingga anak-anak akan nyaman berlama-lama di sekolah. Sekolah Islam Ibnu Hajar merupakan sekolah yang berbasis STIFIn yaitu sekolah yang memfasilitasi potensi genetik yang di yang dimiliki setiap anak. Potensi genetik ini dimiliki oleh anak sejak lahir dan berbeda-beda setiap anak. Dengan menerapkan konsep STIFIn akan lebih mempermudah dalam memahami karakter siswa dan menunjang keefektifan dalam belajar dan mengajar.

Sekolah Islam Ibnu Hajar didirikan pada tahun 2010 dan membuka layanan pendidikan jenjang Sekolah Dasar (SD). Kegiatan persekolahan di mulai pada tahun ajaran 2010/2011 dengan jumlah siswa sebanyak 48 orang yang terbagi kedalam 2 Rombongan Belajar, memanfaatkan ruang-ruang kelas yang berada di Gedung Pusat Pengembangan Islam Bogor (PPIB) yang beralamat di Jalan Raya Padjajaran.

Bertepatan dengan di mulainya tahun ajaran 2014/2015, Sekolah Islam Ibnu Hajar menempati lokasi baru pada lahan seluas 5 ha (50.000 meter persegi) di wilayah Kelurahan Katulampa Bogor di lahan yang masih asri dengan kehijauan lingkungan dan pemandangan Gunung Salak ini, berdiri bangunan-bangunan bambu yang digunakan sebagai ruang kelas tempat belajar-mengajar.

Minat masyarakat terhadap Sekolah Islam Ibnu Hajar terus meningkat, sehingga pada tahun ajaran 2016/2017 Sekolah Islam Ibnu Hajar mulai membuka penerimaan siswa baru jenjang Sekolah Menengah Pertama (SMP) pada januari 2018.

Sekolah inklusi adalah sekolah dimana semua anak dapat bergabung, berinteraksi dan belajar bersama baik anak berkebutuhan khusus (ABK) maupun anak tanpa kebutuhan khusus (ATBK). ABK adalah anak yang memang membutuhkan perhatian, perlakuan bahkan fasilitas khusus sebagai penunjang pembelajarannya. Untuk membantu dan mendukung berjalannya sekolah inklusi dengan baik dan efektif, Sekolah Islam Ibnu

Hajar sudah memiliki psikologi anak engan keahlian ABA (Applied Behavior Analysis), Phisyioterapist dan Guru Pendamping Khusus, sehingga siswa yang di kategorikan sebagai ABK (Anak Berkebutuhan Khusus) yang bersekolah di Sekolah Islam Ibnu Hajar dapat mendapatkan pelayanan yang terbaik mulai dari pelayanan kebutuhan dalam pembelajaran maupun keutuhan sosial lainnya.

Minat masyarakat terhadap Sekolah Islam Ibnu Hajar semakin terus meningkat, sehingga pada tahun ajaran 2019/2020 Sekolah Islam Ibnu Hajar mulai membuka penerimaan siswa baru jenjang SMA yang di beri nama SMZ. Sekolah Menengah Generasi-Z adalah sekolah yang berfokus pada penggemblengan personality genetik. Artinya setiap anak diharapkan memaksimalkan potensi genetiknya

Untuk memudahkan para orang tua menyekolahkan anaknya dalam satu sekolah, Sekolah Islam Ibnu Hajar mulai membuka penerimaan siswa baru jenjang taman kanakkanak dan Play Group pada tahun ajaran 2020/2021.

Visi dan Misi Sekolah Islam Ibnu Hajar 
Visi Sekolah Islam Ibnu Hajar adalah "Menjadi Model Sekolah Penggemblengan Profesi berbasis Jenius Lokal Berakhlakul Karimah sesuai Personaliti Genetik Individu di tahun 2020". Sementara Misi Sekolah Islam Ibnu Hajar adalah "Membangun Generasi Rahmatan Lil'Alamiin"

Penjelasan dari visi tersebut adalah menjadi model sekolah yang dimaksud adalah sebuah proses eksperimentasi dalam membuat miniatur sekolah yang berfokus pada penggemblengan profesi berbasis jenius lokal dimana proses penggemblengan tersebut di dasarkan pada potensi genetiknya.

Penjelasan misi ini mengandung makna bahwa kehadiran Sekolah Islam Ibnu Hajar adalah bagian dari upaya mewujudkan Islam yang Rahmatan lil'Alamiin generasi yang mencapai kesuksesan dan kemuliaan hidup yang di landasi oleh kekokohan iman kepada Allah SWT.

\section{Struktur Organisasi dan Uraian Tugas}

Struktur Organisasi merupakan salah satu dalam pencapaian tujuan dan sasaran organisasi serta wewenang dan tanggung jawab tiap-tiap anggota organisasi pada setiap pekerjaan, sehingga struktur organisasi di buat secara sederhana ,efektif untuk dapat bekerja secara efisien. Selain itu, struktur organisasi sering di sebut bagan atau skema organisasi, dengan ini gambaran skematis tentang hubungan pekerjaan antara orang yang terdapat dalam suatu badan atau perusahaan untuk mencapai tujuan.

Demikian pula halnya dengan Sekolah Islam Ibnu Hajar. Pegawainya melakukan pekerjaan masing-masing sesuai dengan tanggung jawabnya, dan satu sama lain saling berhubungan dalam usaha menciptakan suasana kerja yang disiplin dan dinamis agar tercapai tujuan perusahaan yang diinginkan. Oleh karena itu suatu organisasi harus dapat menggambarkan secara jelas fungsi dari tiap-tiap bagian yang terdapat pada organisasi tersebut. Adapun struktur organisasi Sekolah Islam Ibnu Hajar adalah sebagai berikut : 


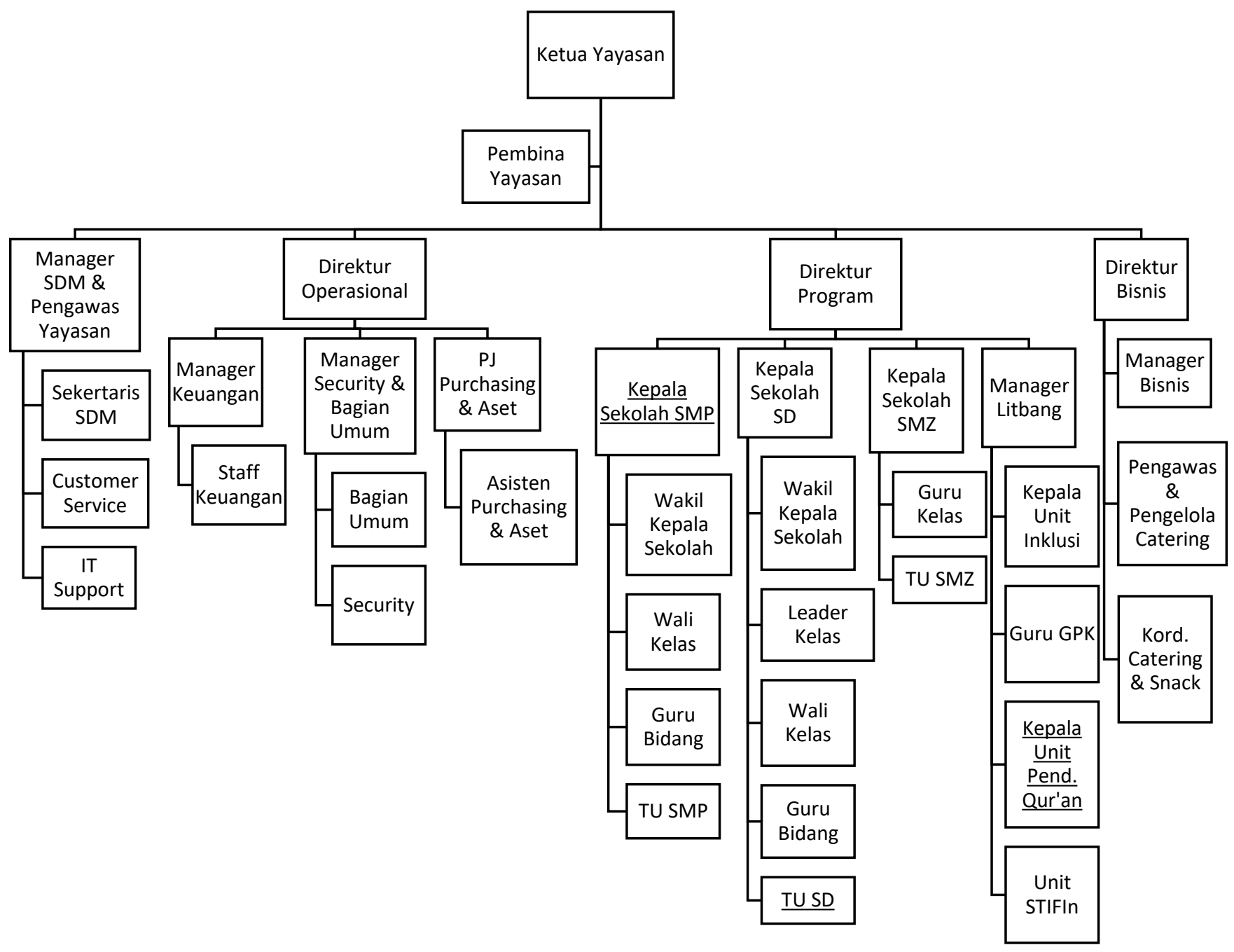

Gambar 1. Struktur organisasi Sekolah Islam Ibnu Hajar Sumber : Sekolah Islam Ibnu Hajar

1. Ketua Yayasan

Ketua yayasan dinilai mempunyai dedikasi yang tinggi untuk mencapai maksud dan tujuan yayasan. Tugas ketua yayasan meliputi :

a. Keputusan mengenai perubahan Anggaran Dasar

b. Pengangkatan dan pemberhentian anggota pengurus dan anggota pengawas

c. Penetapan kebijakan umum yayasan berdasarkan Anggaran Dasar yayasan

d. Pengesahan program kerja dan rancangan anggaran tahunan yayasan

e. Menetapkan kebijakan umum yayasan

f. Bertanggung jawab atas yayasan

2. Pembina Yayasan

Pembina yayasan bertanggung jawab atas keberlangsungan yayasan

3. Manajer SDM

a. Merencanakan dan mengkordinasikan tenaga kerja perusahaan yang hanya memperkerjakan karyawan yang berbakat

b. Menjadi penghubung manajamen dengan karyawannya

c. Merekrut dan memberhentikan SDM 
d. Memperhatikan kinerja SDM

e. Tempat penyampaian pendapat/ keluhan SDM

f. Pengangkatan karyawan dari kontrak penjadi pegawai tetap yayasan

4. Sekertaris SDM
a. Membantu Kinerja Manajer SDM
b. Memasang informasi Lowongan kerja baik secara online maupun offline
c. Memeriksa data pelamar yang masuk pada email
d. Membuat surat kontrak kerja, surat pengangkatan karyawan, dll
e. Menghubungi pelamar kerja untuk mengikuti tes calon karyawan
f. Mengelola daftar hadir pegawai

5. Customer Service
a. Menanggapi pertanyaan dari orang tua murid
b. Menjawab panggilan telpon,faks dan email
c. Mengenalkan tentang Sekolah Islam Ibnu Hajar
d. Memproses pesanan formulir
e. Menyimpan catatan interaksi pelanggan, transaksi, komentar, dan keluhan berkomunikasi
f. Berkodinasi dengan kolega, perwakilan layanan pelanggan junior
g. Memverifikasi data penjemput siswa

6. IT Support
a. Memastikan koneksi wifi bagus
b. Memperbaiki koneksi wifi jika ada kerusakan
c. Memperbaiki Komputer jika terjadi kerusakan

7. Direktur operasional
a. Bertanggung jawab atas operasional sekolah
b. Bertanggung jawab atas sumber dan sekolah
c. Menyetujui/tidak program yang di jalankan sekolah

8. Manajer Keuangan
a. Mengurus pemasukan dan pengeluaran sekolah
b. Mengurus gaji karyawan
c. Mengurus dana program siswa
d. Mengurus dana operasional kelas

9. Staf Keuangan

a. Membantu kinerja manajer keuangan

b. Membuat slip gaji karyawan

c. Bertanggung jawab atas pemasukan uang spp, infaq, tabungan lain-lain atau dana lainnya

10. Manajer Security dan bagian umum
a. Mengurus kinerja satpam
b. Memastikan keamanan sekolah
c. Bertanggung jawab atas peminjaman aula
d. Memastikan ketersediaan fasilitas umum untuk siswa,guru maupun SDM lainnya

11. Bagian Umum
a. Membersihkan lingkungan sekolah
b. Membersihkan kelas, dan semua ruangan yang ada di sekolah
c. Memelihara tumbuhan yang ada di lingkungan sekolah
d. Memastikan ketersediaan air minum untuk siswa,guru, maupun SDM lainnya
e. Memperbaiki jika ada sarana dan prasarana sekolah yang rusak

12. Penanggung Jawab Purchasing dan Aset

Bertanggung jawab untuk memastikan fasilitas kelas terpenuhi seperti fasilitas mengajar,kebersihan dan operasional kelas.

13. Asisten Purchasing dan Aset

Bertugas untuk membantu kinerja Penanggung Jawab purchasing dan asset 


\section{Direktur Program}

a. Membuat program tahunan

b. Memastikan semua program yang dibuat berjalan

c. Memimpin terlaksannya program sekolah

d. Memilih, menetapkan kebijakan sekolah

e. Mengawasi kinerja SDM serta tugas-tugasnya

15. Kepala Sekolah

a. Bertanggung jawab atas segala permasalahan yang ada di sekolah

b. Bertanggung jawab atas program-program sekolah

c. Menerima saran dan masukan guru terhadap keluhan orang tua murid atau permasalahan yang terjadi di sekolah

d. Membimbing guru dalam hal menyusun dan menjalankan program pengajaran

e. Mengikuti perkembangan IPTEK melalui pendidikan/latihan, pertemuan seminar, diskusi, dll.

16. Wakil Kepala Sekolah

Bertugas membantu bertanggung jawab Kepala Sekolah dalam :

a. Menyusun perencanaan,membuat program kegiatan dan program pelaksanaan

b. Pengorganisasian

c. Pengarahan

d. Pengawasan

e. Penilaian

f. Identifikasi dan pengumpulan data

g. Mewakili Kepala Sekolah untuk menghadiri rapat, khususnya yang berkaitan dengan pendidkan

h. Mengurus ekstrakulikuler

17. Leader Level

a. Menjadi ketua atau kepala pada setiap level kelas

b. Memastikan rencana pembelajaran berjalan dengan baik

c. Memberikan pelatihan kepada rekan-rekan kerja

18. Wali Kelas

a. Mengajar dan medidik siswa

b. Membimbing pada saat kegiatan di luar seperti : camping, home visit, kunjungan edukasi, dll.

19. Guru Bidang

Bertugas mengajarkan pembelajaran mata pelajaran di luar mata pelajaran kelas seperti: Bahasa arab, bahasa Inggris, bahasa sunda

20. Manajer Litbang

a. Bertanggung jawab atas kebutuhan anak ABK

b. Menjalankan program STIFIn

c. Memberikan pelatihan kepada guru pendamping khusus (GPK)

21. Guru Pendamping Khusus (GPK)

a. Mendampingi proses pembelajaran Anak Berkebutuhan Khusus (ABK)

b. Memberikan treatment sesuai program yang telah diberikan

c. Membuat laporan pendampingan Anak Berkebutuhan Khusus (ABK)

d. Berkoordinasi dengan leader dan guru kelas untuk pendampingan Anak Berkebutuhan Khusus (ABK)

e. Memastikan pendampingan ABK berjalan lancar

22. Kordinator Inklusi
a. Mengawasi kinerja GPK
b. Memantau perkembangan ABK
c. Berkordinasi dengan Psikolog dan Fisiotherapy
d. Memfasilitasi laporan perkembangan ABK 
23. Tata Usaha

Tata usaha memiliki administrasi yang meliputi kepegawaian, adiministasi kesiswaan, keuangan administrasi sarana dan prasarana, administrasi persuratan dan administrasi kearsipan

a. Mengisi buku induk pegawai

b. Melayani pendaftaran siswa baru

c. Membuat daftar nomor induk siswa

d. Mengelola buku ekspedisi persuratan

e. Mengelola surat masuk dan keluar

f. Membantu proses kegiatan komite

g. Membuat laporan penggunaan keuangan

h. Menyusun arsip dan file pegawai

24. Direktur Bisnis

a. Bertanggung jawab atas keberlangsungan bisnis di sekolah seperti kantin koperasi dll.

b. Membuat program bisnis untuk mencari laba

25. Manajer Bisnis

a. Mengawasi keberlangsungan bisnis di sekolah

b. Membantu membuat program bisnis

26. Kordinator snack dan catering

a. Bertanggung jawab atas keberlangsungan catering anak

b. Memberikan informasi kepada vendor

c. Memberikan menu catering dan snack anak

\section{Sumber Daya Manusia}

Operasional Sekolah Islam Ibnu Hajar saat ini didukung oleh 154 karyawan. Yang terbagi 1 orang sebagai ketua yayasan, 1 orang sebagai manajer SDM dan pengawas yayasan, 1 orang sebagai direktur operasional, 1 orang sebagi Pembina yayasan 1 orang sebagai direktur bisnis, 1 orang sebagi manager bisnis, 1 orang sebagai pengawas dan pengelola catering, 1 orang sebagai wakil, 1 orang sebagai manajer keuangan, 1 orang sebagai manajer security dan bagian umum.108 orang sebagai fasilitator atau tenaga pengajar dengan latar pendidikan formal lulusan S1 untuk guru kelas dan SLTA untuk Guru Pendamping, 16 orang sebagai tenaga staf, 12 orang sebagai tenaga keamanan/security dengan latar pendidikan SLTA, 6 orang sebagai tenaga kebersihan/Office Boy, 2 orang sebagai tenaga supir.

Sekolah Islam Ibnu Hajar saat ini berada di Jln Raya Katulampa RT 01 RW 01, Kelurahan Katulampa, Kecamatan Bogor Timur, Kota Bogor Jawa Barat Kode Pos 16144.

Tabel 1. Sumber daya Manusia Berdasarkan Pendidikan

\begin{tabular}{|c|c|}
\hline Pendidikan & Jumlah \\
\hline SLTA & 36 Orang \\
\hline D3 & 4 Orang \\
\hline S1 & 114 Orang \\
\hline Jumlah & 154 Orang \\
\hline
\end{tabular}

Sumber : Sekolah Islam Ibnu Hajar 
Tabel 2. Sumber daya Manusia Berdasarkan Jabatan

\begin{tabular}{|c|c|}
\hline Jabatan & Jumlah \\
\hline Ketua Yayasan & 1 orang \\
\hline Manager SDM & 1 orang \\
\hline Direktur Operasional & 1 orang \\
\hline Pembina Yayasan & 1 orang \\
\hline Direktur Bisnis & 1 orang \\
\hline Manager Bisnis & 1 orang \\
\hline Pengawas dan pengelola Catering & 1 orang \\
\hline Wakil Direktur & 1 orang \\
\hline Manager Keuangan & 1 orang \\
\hline Manager Security dan Bagian umum & 1 orang \\
\hline Fasilitator (tenaga pengajar) & 86 orang \\
\hline Guru Pendamping Khusus & 22 orang \\
\hline Staf & 16 orang \\
\hline Security & 12 orang \\
\hline Office Boy & 6 orang \\
\hline Tenaga supir & 2 orang \\
\hline Jumlah & 154 orang \\
\hline
\end{tabular}

Sumber : Sekolah Islam Ibnu Hajar

\section{Sarana dan Prasarana}

Sarana dan prasarana adalah faktor penting pendukung kegiatan di sekolah. Adanyan sarana dan prasarana yang memadai sehingga kegiatan di sekolah bisa berjalan lebih optimal. Tak di pungkiri, sarana dan prasarana yang memadai dapat mewujudkan kenyamanan dalam menajalankan kegiatan di sekolah sehingga dapat memacu kinerja untuk mengembangkan semua potensi yang di miliki sarana dan prasarana yang tersedia dan menunjang kegiatan di Sekolah Islam Ibnu Hajar

1. Komputer

Berjumlah 19 unit terdiri dari 1 unit untuk bagian STIFIn, 1 unit untuk bagian litbang, 1 unit untuk bagian PJ purchasing, 1 unit untuk bagian Customer Service, 5 unit untuk bagian keuangan, 2 unit untuk bagian tata usaha (TU), 6 unit bagian untuk kepala sekolah, dan 2 unit bagian leader.

2. Mesin fotocopy

Berjumlah satu unit mesin fotocopy yang terletak di perpustakaan.

3. Printer

Berjumlah 8 unit mesin printer terdiri dari, 1 unit untuk bagian litbang, 2 unit untuk bagian tata usaha (TU), 3 unit untuk bagian keuangan dan 2 unit untuk bagian SDM.

4. Dispenser

Berjumlah 38 unit dispenser terdiri dari, 26 unit utuk level 1 sampai 6, 1 unit untuk bagian litbang, 1 unit untuk bagian Customer Service, 2 unit untuk bagian guru mapel ikhwan dan akhwat masing-masing 1 unit, 1 unit untuk bagian satpam, 1 unit untuk bagian keuangan, 2 unit untuk bagian leader ikhwan dan akhwat masing-masing 1 unit, 1 unit untuk bagian SDM, 1 unit untuk bagian keuangan 1 unit untuk bagian tata usaha (TU) dan 1 unit untuk bagian STIFIn.

5. Lemari

Berjumlah 41 unit lemari masing masing 1 unit lemari setiap ruangan dan kelas.

6. Meja

Berjumlah 135 unit meja yang terdiri dari 5 unit untuk bagian keuangan, 2 unit untuk bagian Customer Service, 1 unit untuk bagian direktur program, 1 unit untuk manajer SDM, 2 unit untuk sekertaris SDM, 4 unit untuk leader akhwat, 3 unit untuk leader ikhwan, 5 unit untuk bagian tata usaha(TU), 2 unit untuk aula, 2 unit untuk bagian SDM, 12 unit untuk guru level 1-6 masing masing 2 unit, 27 untuk level 7 untuk guru 3 unit dan untuk siswa 24 unit, 27 untuk level 8 untuk guru 3 unit dan untuk siswa 
24 unit dan 25 untuk level 825 unit untuk guru 3 unit, untuk siswa 22 unit,5 unit untuk bagian litbang, 8 unit untuk bagian guru mapel ikhwan dan akhwat masingmasing 4 unit, 1 unit untuk bagian STIFIn dan 3 unit untuk perpustakaan.

7. Kursi

Berjumlah 100 unit terdiri dari 3 unit untuk bagian STIFIn, 7 unit untuk bagian keuangan, 4 unit untuk bagian Customer Service, 5 unit untuk bagian tata usaha (TU), 3 unit untuk bagian direktur program, 3 unit untuk bagian manajer SDM, 2 unit untuk bagian sekertaris SDM 6 unit untuk bagian kepala sekolah, 12 unit untuk bagian guru level 1-6, 27 unit untuk level 7, 27 untuk level 8 dan 25 untuk level 9.

8. Alat treatment

Beberapa jumlah alat treatment untuk menunjang kebutuhan Anak Berkebutuhan Khusus ( ABK ) seperti : bola basket, flash card, jepitan, sandbag, kartu domino, cat air, playdough dll.

9. Ruang kelas

Berjumlah 26 ruang kelas terdiri dari 4 ruang kelas untuk level satu, 4 ruang kelas untuk level 2, 4 ruang kelas untuk level 3, 4 ruang kelas untuk level 4, 6 ruang kelas untuk level 5 dan 6 masing - masing 3 ruang kelas. 3 ruang kelas untuk level 7,8 dan 9 masing - masing satu kelas, dan satu ruang kelas untuk level 10 (SMZ).

10. Ruangan

Berjumlah 15 ruangan terdiri dari, 1 ruangan satpam, 1 ruangan TU keuangan, 1 ruang purchasing, 1 ruang leader ikhwan, 1 ruang leader akhwat, 1 ruangan TU admin, 2 ruang kepala sekolah, 1 ruang wakil kepala sekolah, 1 ruang direktur program, 1 ruang SDM, 1 ruang guru mapel ikhwan, 1 ruang guru mapel akhwat, 1 ruang bagian umum dan 1 ruang litbang.

11. Lahan parkir

Berjumlah 6 lahan parkir terdiri dari 2 lahan parkir untuk karyawan, 1 lahan parkir sepeda, 1 lahan parkir motor untuk orang tua dan tamu dan 2 lahan parkir untuk mobil untuk orang tua dan tamu.

12. Toilet

Terdapat 26 toilet masing- masing untuk toilet ikhwan dan akhwat.

13. Dapur

Terdapat satu dapur yang terletak di dekat lingkungan SMP.

14. Gudang

Terdapat satu gudang yang terletak di dekat ruang mapel.

15. Perpustakaan

Terdapat 1 ruang perpustakaan di dekat kelas 3.

16. Masjid

Terdapat satu masjid yang terletak di dekat kelas 5 dan 6 .

17. Lapangan

Berjumlah 2 lapangan yang terdiri dari 1 lapangan olahraga dan 1 lapangan teater.

18. Kantin dan Koperasi

Kantin dan koperasi yang terletak di dekat kebun jati.

19. Perpustakaan

Terdapat 1 ruang perpustakaan untuk menunjang fasilitas belajar mengajar.

\section{Uraian Singkat Magang}

Pelayanan Customer Service di Sekolah Islam Ibnu Hajar berlangsung selama 5 hari kerja yaitu dari hari Senin- Jumat dari pukul 09.00 -16.00 baik secara online maupun offline.

Penulis bekerja di Sekolah Islam Ibnu Hajar pada 16 Juli 2018 - 22 juni 2020 dengan jadwal kerja Senin - Jumat pukul 07.30 - 16.00. Pada saat bekerja penulis di tempatkan di bagian Litbang sebagi Guru Pendamping Khusus. Tugas Guru Pendamping Khusus adalah membantu anak-anak yang memiliki kebutuhan khusus, anak anak yang istimewa atau anak anak yang memiliki gangguan belajar, gangguan fokus dan konsentrasi dan lain-lain. Selain membantu dalam hal belajar. 
Guru Pendamping Khusus juga di tuntut untuk memberikan treatment atau stimulus intensif kepada anak anak spesial tersebut setiap hari, stimulus intensif tersebut di berikan langsung oleh fisioterapi dan psikolog anak, tergantung dengan diganosa anak-anak tersebut. Diagnosa tersebut diantaranya:

1. ADHD (attention deficit hyperactivity disorder) adalah ganguan mental yang menyebabkan seorang anak sulit memusatkan perhatian serta memiliki perilaku implusif dan hiperaktif, sehinggan berdampak pada prestasi anak di sekolah. Gejala utama ADHD adalah sulit memusatkan perhatian tidak bisa diam dan selalu ingin bergerak

2. Disleksia adalah ganguan dalam proses belajar yang di tandai dengan kesulitan membaca,menulis dan mengeja serta kesulitan mengidentifikasi kata yang di ucapkan dan mengubahnya menjadi huruf atau kalimat. Disleksia tergolong ganguan saraf pada bagian otak yang memproses bahasa dan dapat di jumpai pada anak-anak dan dewasa, meskipun individu dengan disleksia kesulitan belajar, penyakit ini tidak mempengaruhi tingkat kecerdasan anak

3. Autisme adalah ganguan perkembangan otak yang mempengaruhi ganguan penderita dalam berkomunikasi dan berinteraksi dengan orang lain. Disamping itu autisme juga menyebabkan ganguan perilaku.

4. Speech Delay adalah gangguan terlambat bicara kondisi dimana seorang anak mendapatkan kesulitan dalam hal mengekpresikan perasaan atau keinginan pada orang lain. Hal ini tampak pada kesulitannya dalam berbicara secara jelas, terhambatnya pola komunikasi dengan orang lain berbeda dengan anak seusianya di sebabkan kuranngnya penguasaan kosakata.

Selama bekerja di Sekolah Islam Ibnu Hajar selama kurang lebih 2 tahun banyak pengalaman yang dapat penulis ambil, pengalaman dan pembelajaran bagaimana cara mengahdapi anak-anak istimewa, Kesabaran sangat penting di terapkan untuk menghadapi anak yang memiliki kebutuhan khusus terutama sabar ketika mendampingi mereka saat belajar, selain belajar, kita juga harus ikhlas dalam mendampingi anak-anak spesial ini. Agar apa yang kita ajarkan bernilai pahala seperti jargon yang harus terapkan oleh Guru Pendamping Khusus yaitu mengabdi, memberi dan menjadi artinya mengabdi yaitu mengabdikan diri sepunuh hati dan penuh keikhlasan untuk membantu anak anak spesial ini, memberi artinya memberi dengan sepenuh hati pembelajaran kepada anak anak spesial ini, dan menjadi artinya di harapakan apa yang telah kita beri kepada anakanak spesial ini menjadi bekal untuk mereka dalam membina diri sendiri di kemudian hari.

Selain itu pada saat bekerja di Sekolah Islam Ibnu Hajar, juga Alhamdulillah bertemu dengan orang-orang yang baik. Selain itu, selama bekerja di Sekolah Islam Ibnu Hajar juga sangat menambah wawasan ilmu agama, dengan kajian-kajian yang di berikan oleh ustadz untuk para karyawan setiap seminggu sekali dengan adanya kajian ini sangat menambah wawasan bagi penulis dalam mengenal agama lebih dalam, terutama belajar ilmu fiqih yang sangat berguna untuk di terapkan kedalam kehidupan sehari-hari.

Selain belajar tentang ilmu fiqih, penulis juga belajar bagaimana cara berpakaian seorang muslim dengan baik menurut agama. Selain mendapatkan ilmu agama para karyawan juga di berikan pelatihan-pelatihan agar menjadi SDM yang lebih berkualitas.

Selain itu selama bekerja di Sekolah Islam Ibnu Hajar juga penulis belajar mengenal lingkungan dan alam di sekitar, selain itu belajar memelihara alam dan lingkungan salah satunya dengan mengurangi penggunaan sampah plastik. Pengalaman bekerja selama kurang lebih 2 tahun ini, akan menjadi pengalaman yang sangat berharga dan tidak akan pernah terlupakan untuk penulis

Penulis melakukan magang pada 7 Februari - 30 April 2020 dengan mewawancarai dan melihat aktifitas Customer Service dalam melakukan pelayanan baik secara online maupun offline.

Banyak pelajaran yang dapat penulis ambil ketika melakukan magang. Yang pertama, arti dari sabar. Sabar ketika menerima segala keluhan pelanggan, sabar dalam menghadapi segala sesuatu, sabar dalam mengendalikan emosi sehingga pada akhirnya 
membuahkan hasil yang manis. Selain itu, kita belajar arti menghargai dan berbicara dengan sopan dan santun. Selain itu penulis juga belajar bagaimana cara melayani pelanggan secara cepat dan tanggap. Cepat artinya tidak bertele-tele dan memakan waktu yang lama dalam memberikan pelayanan yang mengakibatkan konsumen bosan dengan pelayanan yang di berikan. Tanggap dalam melayani keinginan dan kebutuhan konsumen. Selain itu penulis juga belajar arti menghargai kepada sesama manusia. Karena terkadang banyak konsumen yang menyampaikan keluhan dengan sikap yang kurang baik, dan ingin segera di layani. Selain penulis juga belajar bagaimana cara memanajemen waktu dengan baik. Memanajemen waktu ketika melakukan pelayanan itu sangat penting, agar pelayanan yang di berikan tidak membuat konsuemen yang di layani merasa bosan dan konsumen yang menunggu tidak merasa terabaikan. Selain itu penulis juga belajar tentang percaya diri bahwa dalam melayani konsumen seorang Customer Service harus mempunyai rasa percaya diri yang tinggi, agar konsumen merasa yakin dan merasa di tangani oleh orang yang tepat, sehingga pelayanan yang di hasilkan akan berkualitas dan konsumen merasa puas terhadap pelayanan yang di berikan.

Selain itu, penulis juga belajar bagaimana cara berkomunikasi yang baik kepada konsumen yang sedang dilayani, cara berkomunikasi yang baik sangat penting ketika Customer Service sedang melakukan pelayanan kepada konsumen, agar tidak ada kesalahpahaman antara Customer Service dengan pelanggan.

Menjadi Seorang Customer Service bukanlah pekerjaan yang mudah, menjadi seorang Customer Service merupakan suatu pekerjaan yang memiliki banyak tuntutan dan keterampilan yang harus dimiliki. Serta harus memiliki sifat professional.

\section{Hasil dan Pembahasan Identifikasi Masalah}

Pelayanan Customer Service di Sekolah Islam Ibnu merupakan jasa yang diberikan oleh Sekolah Islam Ibnu Hajar kepada orang tua dan calon orang tua serta siswa dan siswi. Fasiltas Customer Service ini di berikan untuk melayani para orang tua dalam menanyakan informasi-informasi mengenai sekolah dan memudahkan para calon orang tua siswa dalam mendapatkan informasi mengenai pendaftaran. Selain itu jika ada calon orang tua yang datang langsung ke sekolah dan ingin mengetahui mengenai lingkungan sekolah petugas Customer Service akan menjelaskannya secara detail sambil membawa calon orang tua siswa untuk berkeliling melihat langsung lingkungan sekolah, agar calon orang tua siswa benar-benar mengetahui tentang lingkungan sekolah. Selain melayani orang tua dan calon orang tua siswa Customer Service juga memberikan pelayanan kepada siswa, yaitu memberikan fasilitas telephone kepada siswa untuk menghubungi orang tua ketika ada keperluan atau penjemputan. Selain itu, petugas Customer Service juga akan memverifikasi data orang yang akan menjemput siswa jika penjemput tidak membawa identitas penjemputan, hal ini dilakukan agar tidak terjadi hal-hal yang tidak di inginkan. dan orang tua tidak merasa khwatir jika penjemputan dilakukan menggunakan transportasi online.

Dengan adanya fasilitas Customer Service ini, Sekolah Islam Ibnu Hajar bermaksud memberikan pelayanan yang cepat,tepat, dan keramahan petugas Customer Service sehingga orang tua merasa nyaman dan terfasilitasi dengan baik oleh sekolah. Dan memberikan wadah kepada orang tua untuk menyampaikan keluhan atau kendala yang di alami serta di berikan solusi yang tepat menggenai keluhan dan kendala yang di alami oleh orang tua siswa.

Dalam rangka menjaga dan kepercayaan konsumen, setiap lembaga harus menjaga citra positif dimata konsumen dan masyarakat, kepercayaan itu sulit didapatkan dan mudah menghilang, untuk menjaga menjaga kepercayaan konsumen pihak sekolah memberikan pelayanan sebaik mungkin kepada konsumen, dengan adanya Customer Service ini, diharapkan mampu memberikan apa yang konsumen butuhkan. Customer Service ini, diharapakan mampu memberikan pelayanan yan optimal, senyum yang ramah, sikap ramah sangat berpengaruh terhadap kesan pertama saat menyapa 
konsumen. Dengan pelayanan yang optimal konsumen akan mendapatkan kesan yang baik. Kesan yang baik dari konsumen akan memberikan citra positif terhadap lembaga.

Untuk meningkatkan kualitas Sekolah, pihak yayasan/ manajemen perlu menyiapkan sumber daya manusia (SDM) yang berkualitas. Yang mampu menangani keinginan dan kebutuhan pelanggan sehingga pelanggan merasa puas dan terlayani dengan baik. Pelatihan dan pengembangan sangat penting, bagi Sumber Daya Manusia agar bekerja lebih menguasai. Selain itu pelatihan yang diberikan kepada sumber daya manusia secara bertahap dan terus dilakukan, dapat meningkatkan kualitas lembaga, karena lembaga tidak akan maju jika tidak memiliki SDM yang baik dan berkualitas.

Perusahaan/lembaga dan Sumber daya manusia merupakan dua hal yang saling membutuhkan. Apabila sumber daya manusia berkualitas akan berhasil membawa kemajuan bagi perusahaan atau lembaga. Keberhasilan ini merupakan sarana menuju pertumbuhan dan perkembangan lembaga. Tujuan yang di capai perusahaan tidak terlepas dari peran dan andil sumber daya manusia yang menjadi penggerak.

\section{Hasil Pembahasan}

Peranan Customer Service dalam meningkatakn mutu pelayanan pada Sekolah Islam Ibnu Hajar dengan memberikan pelayanan yang cepat, tepat dan ramah sehingga para orang tua merasa terlayani dengan baik

\section{Strategi Pelayanan Customer Service Sekolah Islam Ibnu Hajar \\ 1. Bersikap ramah}

Customer Service harus melayani siswa dan orang tua siswa dengan sikap yang ramah agar mereka merasakan kenyamanan ketika ingin menanyakan suatu informasi maupun keluhan seperti : informasi tentang profil sekolah, jemputan siswa dan lain lain. Mengawasi komunikasi dengan memberikan salam yang hangat. Melayani dengan ramah mampu menciptakan keakraban dengan konsumen, dengan bersikap ramah dapat meningkatkan citra diri Customer Service. Dan tentunya juga citra lembaga keramahan yang Customer Service berikan akan memudahakan untuk mengingat konsumen sehingga mereka menjadi konsumen yang setia. Selain itu sikap ramah sangat penting dalam memberikan pelayanan kepada pelanggan, sikap ini penting untuk menciptakan suasana santai/rileks dari pelanggan sehingga pelanggan akan lebih mudah menyampaikan keinginannya dan Customer Service akan lebih mudah memahaminya. Hal ini dapat menghindari kemungkinanan timbulnya kesalahan untuk memahami keinginanan pelanggan. Sikap ramah dapat di kembangkan dengan cara :
a. Menciptakan suasana hati yang riang
b. Melupakan hal yang menjengkelkan
c. Wajah yang ceria/fresh
d. Nada suara yang hangat dan bersahabat
e. Tidak membedakan pelanggan

\section{Komunikatif}

Customer Service memiliki keahliaan di bidang komunikasi, keahlian tersebut merupakan salah satu keahlian yang sangat penting karena seorang Customer Service harus berbicara dengan sopan santun dan terarah, karena seorang Customer Service akan lebih mudah membantu menyelesaikan permasalahan konsumennya bila memahami metode komunikasi yang efektif, terhadap konsumen. Dengan komunikasi yang baik Customer Service dapat meyakinkan konsumen.

Selain itu kemampuan komunikasi yang baik juga dibutuhkan oleh seorang Customer Service, karena seorang Customer Service adalah garda terdepan dalam melayani sekaligus menghadapi konsumen yang mengajukan komplain. Pentingnya kemampuan komunikasi sebagai senjata ampuh untuk menghadapi berbagai persoalan. 
Komunikasi kepada konsumen bukanlah perkara yang mudah, namun juga bukan perkara yang sulit, karena konsumen merupakan individu yang unik. Dimana keinginan pelanggan yang satu belum tentu sama dengan yang lainnya. Keberhasilan komunikasi pada intinya di tentukan atas 3 elemen dimana $7 \%$ oleh kata-kata, 38\% oleh suara (cara mengucapkannya), dan 55\%oleh bahasa tubuh. Untuk itu ketiga elemen tersebut perlu diperhatikan lebih mendalam:

1. Kata-kata

a. Gunakan kata-kata yang tepat yang mendorong konsumen untuk membayangkan sesuatu seperti informasi yang disampaikan kepadanya.

b. Hindari penggunaan kata-kata atau istilah atau jargon yang membuat pelanggan bingung dan tidak paham, terhadap informasi yang di sampaikan oleh Customer Service

2. Suara

Hal-hal yang perlu di perhatikan dalam suara antara lain:

a. Aturlah Volume suara (tidak terlalu rendah dan tidak terlalu tinggi)

b. Berbicara dengan artikulasi yang jelas yang memudahkan konsumen menangkap maksud yang ingin di sampaikan

c. Atur kecepatan bicara, sehingga tidak terlalu cepat dan tidak terlalu lambat.

3. Bahasa tubuh

a. Senyum selama pembicaraan akan memberikan gambaran bahwa kita memberikan empati kepada pelanggan

b. Jaga jarak dengan pelanggan saat berbicara tidak terlalu dekat dan tidak terlalu jauh

c. Atur pergerakan tangan kaki, kepala, kepala tubuh saat berbicara

Komunikasi dalam melakukan pelayanan terhadap konsumen, tidak hanya melalui tatap muka tetapi bisa juga melalui telepon. Ada beberapa hal uang perlu dilakukan oleh seorang Customer Service, jika melakukan pelayanan terhadap konsumen melalui telepon diantaranya adalah :

a. Angkat telepon sehingga konsumen tidak menunggu terlalu lama

b. Dengarkan informasi atau keluhan yang di sampaikan oleh konsumen dengan baik

c. Catat segala informasi atau keluhan yang disampaikan konsumen

d. Tunjukkan pengertian dan empati yang ditunjukkan melalui suara

e. Sebut nama konsumen yang menelepon dengan baik sehingga akan terbangun suasana keakraban

f. Tunjukkan keinginan untuk membantu kepada konsumen

g. Berikan informasi yang komplit dan akurat sehingga pelanggan akan merasa segala informasi yang dibutuhkan terpenuhi

h. Segera respon dan ambil tindakan yang tepat.

\section{Sabar}

Sabar dalam melayani konsumen sangatlah diperlukan agar pelanggan senang dan nyaman, sifat sabar akan sangat membantu dalam memberikan kepuasan terhadap pelayanan yang di berikan kepada konsumen. Seorang Customer Service harus melayani dengan penuh kesabaran, sabar ketika harus menangani keluhan konsumen. Sabar ketika konsumen menyampaikan maksud dan keinginanannya dengan bahasa yang kurang sopan. Jika Seorang Customer Service tidak bisa menerapkan sifat sabar ketika melayani maka pelayanan yang baik atau pelayanan prima tidak akan terwujud.

Sabar merupakan salah satu sifat mental yang harus di miliki oleh seorang Customer Service. Terutama sabar dalam menghadapi komplain. Komplain merupakan bagian yang sangat membutuhkan kesabaran bagi seorang Customer Service, dengarkan apa yang di sampaikan oleh pelanggan. Biarkan mereka menumpahkan segala unek-unek dan kekesalan serta kekecewaan yang mereka sampaikan. Tidak perlu menyelak atau memotong pembicaraan cukup merespon dengan anggukan atau ucapah "oh iya" 
sebagai tanda Customer Service mendengarkan dan memperhatikan keluhan mereka. Setelah konsumen mengeluarkan semua komplain yang dialami barulah Customer Service memberikan solusi yang tepat. Mental yang kuat dalam melayani konsumen, dapat memberikan kepercayaan diri yang lebih baik dan menimbulkan sifat kejujuran maupun tanggung jawab yang besar terhadapa apa yang di lakukan.

\section{Mampu Mengendalikan emosi}

Seorang Customer Service harus mampu mengendalikan emosi, dalam melakukan pelayanan biasanya ada konsumen yang menyampaikan keluhan dengan sikap atau bahasa yang kurang sopan, tidak boleh terpancing dan tetap menunjukan empati dan penghargaan kepadanya. Oleh karena itu seorang Customer Service harus mampu mengendalikan emosi untuk menghindari perselisihan dengan konsumen. Jika sebelumnya telah menghadapi konsumen yang komplain, dan datang kembali kosumen yang lain tidak boleh meluapkan kepada konsumen yang lain, harus dapat mengendalikan emosi dan memberikan informasi kepada konsumen tersebut dengan energik.

\section{Cepat Tanggap}

Seorang Customer Service dituntut untuk cepat dalam melayani konsumen/orang tua, cepat melayani apa yang menjadi kebutuhan/keinginan konsumen. Kecepatan dalam pelayanan akan memberikan citra positif terhadap lembaga/sekolah karena kecepatan pelayanan konsumen merasa bahwa segala apa yang menjadi kebutuhan konsumen difasilitasi dengan baik oleh pihak lembaga/ sekolah. Kecepatan dalam penanganan keluhan yang di sampaikan oleh konsumen, karena kecepatan penanganan keluhan akan mengubah seorang konsumen yang tidak puas menjadi puas, dan meminimalkan dampak negative, akibat kegagalan layanan atau jasa. Keluhan yang tidak ditangani dengan cepat akan menimbulkan ketidakpuasan, dan dapat merusak citra lembaga Selain cepat seorang Customer Service juga harus tanggap. Tanggap terhadap apa yang menjadi keinginanan dan kebutuhan konsumen, selain itu Customer Service juga harus tanggap dalam menghadapi keluhan yang disampaikan oleh konsumen, serta tanggap memberikan solusi terhadap keluhan yang disampaikan oleh konsumen.

\section{Kenyamanan}

Terkadang ada konsumen yang kritis dan rasional yang meminta kenyamanan suasana ketika dilakukan pelayanan. Oleh karena itu meja Customer Service harus selalu rapi dan bersih. Harus pandai menata pernak-pernik dimejanya, hindari kesan kusut dan berantakan diatas meja seperti penataan brosur, kalender meja, register, dan sebaginya, hindari juga ketidakrapihan penataan pernak-pernaik disekitar meja kerja sehingga ketika konsumen melakukan interaksi dengan Customer Service terasa nyaman.

Membuat pelayanan konsumen menjadi nyaman, berarti membuat pengalaman pelayanan berjalan dengan tenang dan aman serta memberikan kesan tersendiri bagi konsumen. Kenyamanan juga akan meningkatkan kualitas pelayanan terhadap konsumen. Oleh karena itu kenyamanan konsumen sangat tergantung dari petugas Customer Service. Kenyamanan juga merupakan komitmen konsumen bertahan secara mendalam untuk berlangganan kembali secara konsisten atau tidak.

Selain itu kenyamanan juga akan sangat berpengaruh dalam membangun kinerja, karena dengan kenyamanan meja kerja Customer Service akan mampu berkonsentrasi dengan baik, ketika melakukan pelayanan. dan menyelesaikan setiap tugas dengan baik tanpa adanya hambatan.

Jadi kenyamanan dalam memberikan pelayanan tidak terjadi begitu saja. Tetapi adanya inisiatif dari seorang Customer Service, dalam menciptakan suasana ruang pelayanan yang baik, kenyamanan ini terjadi karena adanya skill yang kreatif dari seorang petugas Customer Service 
Kendala-Kendala Customer Service dalam Meningkatkan Mutu Pelayanan di Sekolah Islam Ibnu Hajar

\section{Meluapkan Keluhan yang Berlebihan}

Konsumen meluapkan keluhan yang berlebihan karena jasa atau pelayanan yang diberikan oleh petugas Customer Service tidak sesuai dengan keinginannya. Konsumen menyampaikan keluhan yang dialami dengan bahasa atau sikap yang kurang sopan, hal ini yang membuat Customer Service sulit untuk memberikan solusi terhadap keluhan yang dialami konsumen.

Keluhan menjadi sumber masukkan atau sebagai feed back yang berharga bagi suatu lembaga untuk lebih meningkatkan kualitas layanannya. Penanganan komplain yang efektif akan sangat berperan bagi lembaga untuk dapat berkembang atau meningkatkan diri lebih baik lagi. Tetapi komplain yang berlebihan dapat menjadi bumerang yang dapat menghancurkan citra lembaga, ketika Customer Service tidak mampu menangani secara efektif. Karena sebenarnya konsumen yang komplain, masih memberikan kesempatan kepada lembaga untuk memberikan kepuasaan kepada mereka. Terutama kepada Customer Service. Customer Service harus menganggap bahwa komplain adalah kesempatan terbaik untuk memuaskan pelanggan.

\section{Minimnya Menghargai Customer Service}

Menjadi seorang Customer Service bukan lah pekerjaan yang mudah, karena menjadi seorang Customer Service harus mempunyai keahlian khusus. Menjadi seorang seorang Customer Service banyak tuntutan-tuntutan yang harus dilakukan, menuntut banyak tatap muka dan melayani konsumen. Dengan pelayanan yang baik, memiliki sifat yang ramah saat melayani konsumen, sopan dan santun ketika berbicara dengan konsumen. Selain itu seorang Customer Service harus mampu, menjaga kepercayaan konsumen. Kepercayaan konsumen merupakan kunci utama untuk mempertahankan konsumen. Seorang Customer Service juga harus berpenampilan menarik dan rapi dan menjalankan pelayanan sesuai dengan standar operasional yang di terapkan lembaga.

Tetapi terkadang, ada konsumen yang datang dengan menyampaikan keluhan dengan sifat dan perilaku yang kurang baik, namun tetap diberikan pelayanan yang baik dan solusi atas keluhan yang dialami, namun konsumen tidak mau menerima solusi yang di berikan oleh Customer Service terhadap keluhan yang dialaminya. Hal ini yang terkadang membuat Customer Service tidak dihargai dan dipandang sebelah mata oleh konsumen, minimnya rasa menghargai terhadap Customer Service. Walaupun demikian seorang Customer Service harus tetap menyikapi dengan penuh rasa sabar.

\section{Hal-hal yang Seharusnya Tidak di tangani Customer Service}

Setiap pekerjaan harusnya di tangani oleh bagian yang seharusnya mengerjakan pekerjaan tersebut, tetapi ada beberapa pekerjaan yang seharusnya tidak di kerjakan oleh bagian Customer Service seperti mengisi data SDM sekolah, seharusnya pekerjaan ini merupakan pekerjaan yang harus di kerjakan oleh bagian SDM, bukan di kerjakan oleh petugas Customer Service, selain itu mengisi data siswa, seharusnya pekerjaan ini di kerjakan oleh bagian unit tata usaha dan admintrasi sekolah.

Hal ini yang menjadi kendala petugas Customer Service, untuk melakukan pelayanan dengan baik. Karena beban pekerjaan yang terlalu banyak yang di bebankan kepada Customer Service.

\section{Keterbatasan Sumber Daya Manusia}

Sekolah Islam Ibnu Hajar hanya memiliki satu Customer Service untuk melakukan pelayanan kepada konsumen, keterbatasannya jumlah Customer Service di Sekolah Islam Ibnu Hajar ini. Membuat kewalahan tenaga Customer Service yang ada saat ini. sehingga ketika melakukan pelayanan kepada konsumen terkadang kurang maksimal, selain itu, kurangnya petugas Customer Service ini yang membuat para konsumen antri dalam melakukan pelayanan kepada Customer Service. sehingga mengakibatkan kekecewan karena harus menunggu dengan waktu yang cukup lama untuk mendapatkan pelayanan oleh petugas Customer Service. 
Selain melakukan pelayanan secara offline atau tatap muka, Customer Service juga melakukan pelayanan secara online. Pelayanan online tidak bisa segera di lakukan/dilayani, karena jika sedang melakukan pelayanan secara offline, tidak sopan rasanya jika seorang Customer Service sambil memegang handpohne. Selain itu jika Customer Service sedang melakukan pelayanan keluar ruangan, untuk menjelaskan lingkungan sekolah secara langsung kepada calon konsumen, dan kemudian ada konsumen yang datang. Hal ini yang menjadi kendala petugas Customer Service dalam meningkatkan mutu/kualitas pelayanan.

Jadi kurangnya petugas Customer Service ini mengakibatkan pelayanan yang diberikan kepada konsumen tidak efektif. Dan menimbulkan masalah-masalah baru yang dialami konsumen.

\section{Waktu}

Dalam melayani konsumen, Customer Service membutuhkan waktu yang cukup lama. konsumen sangat membutuhkan waktu yang cukup lama, untuk di lakukan pelayanan. Oleh Customer Service. Jika Customer Sevice membutuhan waktu yang lama untuk melakukan pelayanan tersebut kepada pelanggan maka konsumen yang sedang menunggu untuk mendapatkan pelayanan dari Customer Service akan merasa bosan, terlebih kepada konsumen yang ingin menyampaikan keluhan, jika menunggu terlalu lama akan menganggap bahwa keluhan yang dialminya, tidak segera ditanggapi dan menimbulkan masalah baru. Selain itu, pelanggan menganggap bahwa pelayanan yang di berikan oleh Customer Service tidak bagus dan dapat mengurangi tingkat kepuasan terhadap pelayanan.

Waktu yang lama, sebenarnya tidak menjamin kualitas pelayanan yang diberikan kepada konsumen akan berkualitas. Tetapi terkadang ada konsumen yang membutuhkan waktu yang lama dalam pelayanan, konsumen biasanya ingin mendapatkan secara detail dan jelas, bahkan terkadang informasi yang di berikan harus disampaikan secara berulang. Padahal Customer Service telah memberikan penjelasan secara detail. Hal ini yang menjadi kendala seorang petugas Customer Service dalam melakukan pelayanan kepada konsumen.

\section{Solusi Customer Service dalam Meningkatkan Mutu Pelayanan pada Sekolah Islam Ibnu} Hajar

\section{Mampu Memanajemen Waktu}

Manajemen waktu merupakan suatu guidline atau panduan yang terdiri dari perencanaan dan cara terhadap seberapa banyak waktu yang di pakai atau di gunakan, untuk menyelesaikan pelayanan. Seorang Customer Service harus mampu memahami bagaiman cara memanajemen waktu yang baik. Manajemen waktu yang baik, dapat membantu Customer Service untuk meningkatkan pelayanan, manajemen waktu perlu dilakukan, untuk membuat pelayanan menjadi lebih efektif. Dalam dunia pelayanan manajamen waktu sangat diperlukan agar pelayanan yang diberikan tidak terlalu lama dan membuat konsumen bosan dengan pelayanan yang diberikan. Dan konsumen yang menunggu untuk di layani, tidak menunggu terlalu lama dan tahu kapan mereka akan dilayani, sehingga tidak membuat konsumen yang menunggu merasa kecewa terhadap pelayanan yang di berikan oleh Customer Service. mereka akan dilayani.

Selain itu, manajemen waktu juga dapat meningatkan skill pelayanan Customer Service. Dengan manajemen waktu dengan baik, seorang petugas Customer Service, mampu mencapai target pelayanan sesuai dengan yang diinginkan. Karena manajamen waktu akan mampu membawa fokus Customer Service terhadap target pencapaian yang sudah tersusun baik. Jadi manajemen waktu dengan baik diharapkan menjadi solusi atas kendala-kendala yang yang dalam melakukan, kegiatan pelayanan.

\section{Kenyamanan}

Kenyamanan dalam proses pelayanan, dapat mempengaruhi kepuasan konsumen. Kenyamanan dapat menumbuhkan dampak positif terhadap pelayanan yang 
diberikan oleh Customer Service. Memberikan kenyamanan kepada konsumen dapat dilakukan dengan beberapa hal diantaranya :

1. Sikap

Sikap Customer Service yang baik dapat memberikan kenyamanan kepada konsumen misalnya dengan, memberikan keramahan dan senyuman dalam hal penyambutan kepada konsumen.

2. Penampilan

Penampilan menjadi salah satu faktor yang membuat nyaman konsumen, dengan berpakain yang bersih, rapi bersih, dan menarik, konsumen akan merasa nyaman ketika diberikan pelayanan oleh petugas Customer Service

3. Komunikasi

Komunikasi/ cara berbicara merupakan salah satu faktor yang membuat kenyamanan pada konsumen, dengan komunikasi yang baik konsumen akan merasakan kenyamanan pada saat mendengarkan informasi atau saran dari keluhan yang dialami, yang di sampaikan oleh petugas Customer Service

4. Ruang pelayanan

Ruang pelayanan menjadi salah satu faktor yang paling penting dalam membuat kenyamanan pada konsumen, ruang pelayanan yang rapi, bersih akan memberikan kesan tersendiri kepada konsumen saat dilakukan pelayanan oleh Customer Service.

5. Keterampilan

Keterampilan/skill yang di miliki oleh Customer Service, merupakan salah satu faktor yang membuat kenyamanan pada konsumen. Keterampilan/skill seorang Customer Service dalam memberikan pelayanan dapat memberikan kenyamanan pada konsumen. Dengan keterampilan yang baik,tentunya seorang Customer Service akan memberikan pelayanan terbaik sesuai dengan keinginan konsumen. Serta dapat memberikan solusi terbaik atas keluhan yang dialami konsumen.

Memberikan kenyamanan dalam pelayanan, memang bukanlah perkara yang mudah. Dalam hal ini seorang Customer Service harus mampu menciptakan kenyaman kepada konsumen yang di layaninya. Karena jika seorang konsumen sudah merasakan kenyamanan bisa jadi mereka akan menjadi konsumen yang setia, dan tentunya akan menimbulkan citra posistf baik untuk Customer Service maupun untuk lembaga.

\section{PENUTUP}

Berdasarkan hasil penjelasan yang telah di uraikan, maka dapat di simpulkan bahwa banyak hal yang menjadi kendala-kendala Customer Service dalam meningkatkan mutu pelayanan di Sekolah Islam Ibnu Hajar :

1. Kendala Customer Service dalam meningkatkan mutu pelayanan di Sekolah Islam Ibnu Hajar diantaranya: meluapkan keluhan yang berlebihan, minimnya menghargai Customers Service, hal-hal yang seharusnya tidak di tangani oleh Customer Service, keterbatasan sumber daya manusia dan waktu. Dari beberapa kendala-kendala tersebut terdapat beberapa solusi. Solusi dari kendala yang pertama yaitu berusaha mendengarkan dengan baik keluhan yang di sampaikan pelanggan dan memberikan solusi yang tepat agar pelanggan merasa bahwa keluhannya di tangani dengan baik. Solusi dari kendala yang kedua yaitu berusaha sabar dan tetap memberikan pelayanan yang terbaik kepada pelanggan. Solusi dari kendala yang ketiga yaitu memberikan masukan kepada atasan bahwa hal tersebut seharusnya tidak dikerjakan oleh Customer Service. Solusi dari kendala yang ke empat yaitu merekrut kembali sumber daya manusia agar pelayanan kepada konsumen yang membutuhkan pelayanan merasa nyaman. Solusi dari masalah yang kelima yaitu dalam melakukan pelayanan terhadap konsumen hendaknya Customer Service menjalankan SOP yang sesuai dengan ketentuan agar konsumen yang sedang menunggu untuk diberikan pelayanan tidak terlalu lama menunggu yang menyebabkan mereka bosan. 
2. Bersikap ramah kepada konsumen agar konsumen yang sedang dilayani merasa nyaman ketika melakukan aktivitas pelayanan seperti memberikan informasi mengenai sekolah kepada orang tua calon siswa baru, memverifikasi data penjemput dengan detail agar orang tua merasa aman dan tidak terjadi hal-hal yang tidak diinginkan, memberikan informasi kepada orang tua siswa dan menanggapi keluhan-keluhan yang disampaikan oleh konsumen. Customer Service juga harus memiliki keahlian di bidang komunikasi, dengan memiliki keahlian komunikasi tersebut Customer Service akan mampu memberikan pelayanan yang baik. Komunikasi yang jelas, mudah dipahami dan tidak berbelit-belit. Jika pelayanan yang diberikan kepada konsumen tidak sesuai dan konsumen merasa tidak puas dengan pelayanan yang diberikan, hal ini akan menimbulkan citra negatif terhadap lembaga dan kepercayaan konsumen akan berkurang. Tetapi jika pelayanan yang diberikan membuat konsumen puas, akan menimbulkan citra positif terhadap lembaga.

\section{DAFTAR PUSTAKA}

Iriyadi, I., Maulana, M. A., \& Nurjanah, Y. (2018, December). Financial Reporting for Micro Small and Medium Enterprises Towards Industrial Revolution Era 4.0. In International Conference On Accounting And Management Science 2018 (pp. 32-38).

Iriyadi, I., Tartilla, N., \& Gusdiani, R. (2020, May). The Effect of Tax Planning and Use of Assets on Profitability with Good Corporate Governance as a Moderating Variable. In 2nd International Seminar on Business, Economics, Social Science and Technology (ISBEST 2019) (pp. 220-227). Atlantis Press.

Martianti, M. A., \& Iriyadi, I. (2020). Peranan Akuntansi Pertanggungjawban Dalam Penilaian Kinerja Pusat Biaya. Jurnal Ilmiah Akuntansi Kesatuan, 8(1), 49-56.

Rosdiana, Y. M., Iriyadi, I., \& Wahyuningsih, D. (2020). Pendampingan Peningkatan Efisiensi Biaya Produksi UMKM Heriyanto Melalui Analisis Biaya Kualitas. Jurnal Abdimas Dedikasi Kesatuan, 1(1), 1-10.

Ajmi, D. N., \& Iriyadi, I. (2018). Analisis Penentuan Tarif Rawat Inap dan Perhitungan Harga Pokok Pada Klinik Utama Rawat Inap dr. Yati Zarnudji. Jurnal Ilmiah Akuntansi Kesatuan, 6(3), 227-238.

Purba, J. H. V., \& Septian, M. R. (2019). Analysis of Short Term Financial Performance: A Case Study of an Energy Service Provider. Journal of Accounting Research, Organization and Economics, 2(2), 113-122.

Purba, J. H. V. (2017). The analysis of European Union's vegetable oil consumption:" will the European Parliament Resolution Halt the Consumption of Crude Palm Oil in the European Union in the future?". International Journal of Applied Business and Economic Research, 15, 19.

Kembauw, E., Munawar, A., Purwanto, M. R., Budiasih, Y., \& Utami, Y. (2020). Strategies of Financial Management Quality Control in Business. Manfacturers' Capital Structure.

Munawar, A. (2020, May). Determinants of Corporates Leverage in Indonesia. In 2nd International Seminar on Business, Economics, Social Science and Technology (ISBEST 2019) (pp. 302-306). Atlantis Press.

Munawar, A. The Effect of Leverage, Dividend Policy, Effectiveness, Efficiency, and Firm Size on Firm Value in Plantation Companies Listed on IDX.

Munawar, A., Syarif, R., \& Morita, M. (2019). Persepsi Mahasiswa Atas Galeri Investasi Perguruan Tinggi dan Pengaruhnya Terhadap Minat Berinvestasi. JAS-PT (Jurnal Analisis Sistem Pendidikan Tinggi Indonesia), 3(2), 89-96.

Sulistiono, S., Fadillah, A., \& Putrie, D. E. (2020, May). Factors Affecting Bogor Botanical Garden Visitors' Intention Before and After the One Way System Application. In 2nd International Seminar on Business, Economics, Social Science and Technology (ISBEST 2019) (pp. 291-296). Atlantis Press. 
Keren, K., \& Sulistiono, S. (2019). Pengaruh Motivasi, Budaya, dan Sikap Konsumen Terhadap Keputusan Pembelian Produk Indomie. Jurnal Ilmiah Manajemen Kesatuan, 7(3), 319-324.

Aziz, M. L., \& Sulistiono, S. (2020). Pengaruh Sikap Konsumen, Periklanan, dan Brand Image Terhadap Minat Beli Konsumen The Jungleland Adventure Theme Park. Jurnal Ilmiah Pariwisata Kesatuan, 1(1), 43-52.

Sinaga, B. A., \& Sulistiono, S. (2020). Pengaruh Electronic Word Of Mouth Dan Promosi Media Sosial Terhadap Minat Beli Pada Produk Fashion Eiger. Jurnal Ilmiah Manajemen Kesatuan, 8(2), 79-94.

Setiawan, B., \& Panduwangi, M. (2017, August). Measurement of Islamic banking attributes in Indonesia. In Proceedings of the Global Conference on Business and Economics Research (GCBER) (Vol. 1415).

Setiawan, B., Afiff, A. Z., \& Heruwasto, I. (2020). Integrating the theory of planned behavior with norm activation in a pro-environmental context. Social Marketing Quarterly, 26(3), 244-258.

Mulyana, M., Mashadi, M., \& Syahputri, A. W. (2020, May). Determinants of Millenial Consumer Purchasing Decisions in Bukalapak. In 2nd International Seminar on Business, Economics, Social Science and Technology (ISBEST 2019) (pp. 113-115). Atlantis Press.

Nurendah, Y., \& Rainanto, B. H. (2019, May). The Analysis of Shoes Marketing Mix in Style Successful Benefits SMEs of Shoes Product in Bogor. In 1st International Conference on Economics, Business, Entrepreneurship, and Finance (ICEBEF 2018). Atlantis Press. 